\title{
Marketing System and Market Integration of Different Egg Markets in Bangladesh
}

\author{
Md. Imran Omar ${ }^{1}$, Ashraful Islam², Mohammad Shamsul Hoq ${ }^{3} \&$ \\ Md. Farid Dewan ${ }^{3}$, and Md.Tauhidul Islam ${ }^{4}$. \\ ${ }^{1 \& 3}$ Scientific officer, Agricultural Economics Division, Bangladesh Agricultural Research Institute, Joydevpur, \\ Gazipur-1701, \\ ${ }^{2}$ Assistant Professor, Department of Dairy and Poultry Science, Patuakhali Science and Technology University, \\ Bangladesh, \\ ${ }^{4}$ Scientific officer, Agronomy Division, Bangladesh Institute of Nuclear Agriculture (BINA), Mymensingh.
}

\begin{abstract}
The objectives of the study were to estimate costs and margins, seasonal price variation and to test market integration of egg. Primary and secondary data were used for this study. The higher marketing cost was incurred by aratdars and the lowest by retailer. On the other hand, retailers earned the highest net marketing margins. Analysis of market integration shows that egg market in Bangladesh was well integrated. The study identified some problems related to economic, technical, marketing, social and natural calamities aspects and suggested some measures for solving these problems.
\end{abstract}

Key words:Engle Granger co-integration,Marketing cost \& Margin, Market integration, Egg.

\section{Introduction}

Bangladesh is a densely populated developing country of 147570 sq. km (BBS, 2000) area with about 145.2 million people (GOB, 2010). The economy of Bangladesh mostly depends on agricultural resources. Approximately eighty five per cent people of the country rely on agriculture in one way or other for their livelihoods. Livestock is an important sub-sector of Bangladesh's agriculture, of which contribution of poultry has risen significantly. The share of livestock sub-sector to total agricultural GDP has increased from 12.72 per cent in 2000-01 to 16.87 per cent in 2011-12 (at current price) in Bangladesh (BBS, 2011). Poultry production and poultry related industry contribute 20.65 per cent of the total livestock contribution (Khan and Roy, 2006). Commercial layer farming is not only a source of employment, income and food but also critical to strong sociocultural linkage ina country like Bangladesh. The demand for egg is increasing with the rapid increase in population. To meet up the increasing demand, apart from egg production, efficient egg marketing is necessary. It is difficult to run a profitable business without proper and organized marketing system. Therefore, marketing is a very important factor for egg as a commercial product. An efficient marketing system is needed for availability of product supply at a fair price and to encourage higher production. For this reason, it is essential to observe the present marketing system, to identify the problems and to improve the marketing system of egg in Bangladesh.

The study provides valuable information for the egg producers, traders and policy makers in Bangladesh to take appropriate decisions regarding further expansion of commercial layer farming and trading. The study makes recommendations for policy measures for improvement of egg marketing with a view to achieving efficiency by analyzing the present marketing problems

The specific objectives of the study are:

$\$$ To determine the marketing cost, margin and price spread in different marketing channels;

* To estimate marketing efficiency in different marketing channels;

* To analyze the market integration of different egg market; and

* To identify the problems of egg marketing and also suggested some remedial measures.

\section{Data sources}

\section{Materials and Methods:}

The present study is based on primary and secondary data. Fifteen egg farmers, 10 arathdars, 15 wholesalers, 10 wholesaler cum retailer, 30 retailers and 5 farias were selected for interview. Primary data were collected in September 2011 through face to face interview with the selected respondents in the study area. Farm level data were collected from Sreepur Upazila of Gazipur district and traders' level data were collected from five markets of Gazipur district. Secondary data were accumulated from FAO publication, official records, books, journals and from the various statistical year books. The weekly average wholesale prices of eggs of 
various markets like Dhaka, Gazipur, Rajshahi, Chittagong, Sylhet, Khulna and Mymensingh during 2000 to 2011 were collected from Department of Agricultural Marketing (DAM). Latter it was converted into monthly figures.

\section{Analytical Techniques:}

Depreciation cost of cage was measured using following formula:

Depreciation cost $=\frac{(\text { Begaining } \cos t-\text { SolvageValue }}{\text { Time }}$

Farmer's net prices, price spread, farmer's gross share and farmer's net share were calculated by using following formulas:

Farmer's net price $=$ Farmer's sale price - Farmer's marketing cost

Price spread $=$ Retail price - Farmer's sale price

Farmer's gross share $=\frac{\text { Farmer's sale price }}{\text { Retail price }} \times 100$

Farmer's net share $=\frac{\text { Farmer's net price }}{\text { Retail price }} \times 100$

Marketing efficiency was calculated using Acharaya's formula:

$\mathrm{ME}=\frac{\mathrm{FP}}{\mathrm{MC}+\mathrm{MM}}$

Where,

ME = Marketing efficiency.

$\mathrm{FP}=$ Net price received by farmers

$\mathrm{MC}=$ Total marketing cost

$\mathrm{MM}=$ Total net marketing margin of intermediaries.

A higher value of ME denotes higher level of efficiency and vice versa.

Market integration: Market integrationwas measured by co-integration method.The bulk of econometric theories have been based on the assumption that the underlying data process is stationary. Stochastic process is said to be stationary if its mean and variance are constant over time and the value of covariance between two time periods depends only on the distance or gap or lag between the two time periods and not the actual time at which the covariance is computed (Gujarati, 2003, p.797). In practice, most economic time series are nonstationary.Aapplying regression models to non-stationary data may arise the problem of "spurious or nonsense" correlation (Gujarati, 2003, p. 792). To overcome such problems, the concept of co-integration was used becauseit offers a means of identifying and hence avoiding the spurious. The underlying principle of cointegration analysis is that, although trend of many economic series show upward or downwards over time in a non-stationary fashion, group of variables may drift together.

Unit Root and Co-integrationTest: The individual price series were tested for the order of integration to determine whether or not they are stationary which is known as the unit root test (Gujarati, 2003, p.799). A number of tests for stationary are available in the literature; these include the Dickey-Fuller (DF) test (Dickey and Fuller, 1979), the Augmented Dickey-Fuller (ADF) test (Dickey and Fuller, 1981) and the Philips-Perron (PP) test (Perron, 1988). For theoretical and practical reasons, the Dickey-Fuller test is applied to regressions run in the following forms:

$\mathrm{Y}_{\mathrm{t}}$ is a random walk or without constant:

$$
\Delta \mathrm{Y}_{\mathrm{t}}=\delta \mathrm{Y}_{\mathrm{t}-1}+\mathrm{e}_{\mathrm{t}}
$$

$\mathrm{Y}_{\mathrm{t}}$ is a random walk with drift or constant:

$$
\Delta \mathrm{Y}_{\mathrm{t}}=\beta_{1}+\delta \mathrm{Y}_{\mathrm{t}-1}+\mathrm{e}_{\mathrm{t}}
$$

$\mathrm{Y}_{\mathrm{t}}$ is a random walk with drift around a stochastic trend (constant plus trend):

$$
\Delta \mathrm{Y}_{\mathrm{t}}=\beta_{1}+\beta_{2} \mathrm{t}+\delta \mathrm{Y}_{\mathrm{t}-1}+\mathrm{e}_{\mathrm{t}}
$$

Where $\mathrm{t}$ is the time or trend variable.

In each case the null hypothesis is $\delta=0(\rho=1)$; that is, there is a unit root in the time series i.e. the series is nonstationary. The alternative hypothesis is that $\delta$ is less than zero; that is, the time series is stationary. Under the 
null hypothesis, the conventionally computed $t$ statistics is known as the $\tau$ (tau) statistic, whose critical values have been tabulated by Dickey and Fuller. If the null hypothesis is rejected, it means that $\mathrm{Y}_{\mathrm{t}}$ is a stationary time series with zero mean in the case of $(1)$, that $Y_{t}$ is stationary with a non-zero mean $\left[=\beta_{1} /(1-\rho)\right]$ in the case of (2), and that $Y_{t}$ is a stationary around a deterministic trend in equation (3).

It is extremely important to note that the critical values of the tau test to test the hypothesis that $\delta=0$, are different for each of the preceding three specifications of the DF test. If the computed absolute value of the tau statistics $(\tau)$ exceeds the DF or MacKinnon critical tau values, we reject the hypothesis that $\delta=0$, in which case the time series is stationary. On the other hand, if the computed $(\tau)$ does not exceed the critical tau value, we do not reject the null hypothesis, were the time series is non-stationary.

In conducting the DF test as in (1), (2), or (3), it was assumed that the error term $e_{t}$ was uncorrelated. But in case the $e_{t}$ are correlated, Dickey and Fuller have developed a test known as the augmented Dickey-Fuller (ADF) test. This test is conducted by "augmenting" the preceding equation by adding the lagged values of the dependent variable $\Delta \mathrm{Y}_{\mathrm{t}}$. The ADF test here consists of estimating if the error term $\mathrm{e}_{\mathrm{t}}$ is auto correlated, one modifies (4) as follows:

$$
\Delta \mathrm{Y}_{\mathrm{t}}=\beta_{1}+\beta_{2} \mathrm{t}+\delta \mathrm{Y}_{\mathrm{t}-1}+\alpha_{\mathrm{i}} \sum_{\mathrm{i}=1}^{\mathrm{m}} \Delta \mathrm{Y}_{\mathrm{t}-\mathrm{i}}+\varepsilon_{\mathrm{t}}
$$

where $\varepsilon_{\mathrm{t}}$ is a pure white noise error term and where, $\Delta \mathrm{Y}_{\mathrm{t}-1}=\left(\mathrm{Y}_{\mathrm{t}-1}{ }^{-} \mathrm{Y}_{\mathrm{t}-2}\right), \Delta \mathrm{Y}_{\mathrm{t}-2}=\left(\mathrm{Y}_{\mathrm{t}-2}-\mathrm{Y}_{\mathrm{t}-3}\right)$, etc., that is, one uses lagged difference terms. The number of lagged difference terms to include is often determined empirically, the idea being to include enough terms so that the error term in (4) is serially uncorrelated. The null hypothesis is still that $\delta=0$ or $\rho=1$, that is, a unit root exists in Y (i.e., Y is non-stationary).

Spatial Price Relationship:To test the market integration, the following co-integration regression was run for each pair of price series:

$$
\mathrm{Y}_{\mathrm{it}}=\alpha_{0}+\alpha_{1} \mathrm{Y}_{\mathrm{jt}}+\varepsilon_{\mathrm{t}}
$$

Where, $Y_{i}$ and $Y_{j}$ are price series of a specific commodity in two markets $i$ and $j$, and $\varepsilon_{t}$ is the residual term assumed to be distributed identically and independently. The test of market integration is straightforward if $Y_{i}$ and $\mathrm{Y}_{\mathrm{j}}$ are stationary variables but if the price series proved as non-stationary then we have to done another test (Engle-Granger test)

Testing whether the variables are co-integrated is merely another unit root test on the residual in equation (5). However, since the $\mathrm{Y}_{\mathrm{i}}$ and $\mathrm{Y}_{\mathrm{j}}$ are individually non-stationary, there is the possibility that the regression is spurious. The DF and ADF tests in the present context are known as Engle-Granger (EG) test whose critical values was provided by Engle-Granger (Ramakumar, 1998). The test involved regression the first-difference of the residual lagged level and lagged dependent variables (Engle-Granger test) is as follows:

For Engle-Granger (EG) test, $\Delta \varepsilon_{\mathrm{t}}=\beta \varepsilon_{\mathrm{t}-1}$

If the computed value of ' $t$ ' of regression coefficient $\beta$ is higher (in absolute term) than tabulated value, our conclusion is that the residuals from the regression are $\mathrm{I}(0)$, that is they are stationary and the regression is not spurious even though individually two variables are non-stationary.

\section{Results and Discussion}

\section{Marketing Channels of Eggs}

The main aim of layer farming is to earn profit by placing the eggs at the disposal of the consumers. It involves a number of important activities at different stages which are performed by a series of intermediaries, linking the producers with the consumers.

The marketing channels of eggs as found in the study areas are shown in Figure 1.

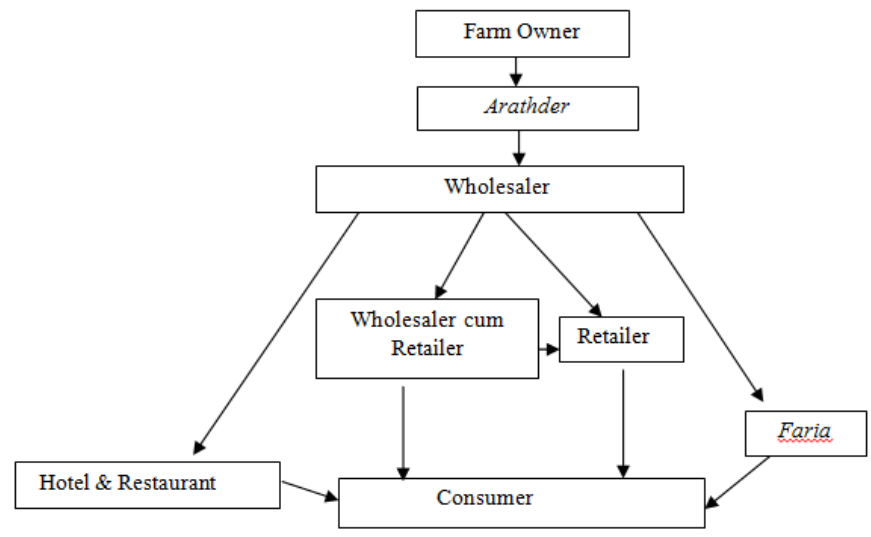

Fig. 1 Marketing channels of Egg in Gazipur district 
Following the fig-1 major marketing channels of the study area were

1: Farm Owner $\rightarrow$ Arathder $\rightarrow$ wholesaler $\rightarrow$ Retailer $\rightarrow$ Consumer

2: Farm Owner $\rightarrow$ Arathder $\rightarrow$ wholesaler $\rightarrow$ Wholesaler Cum Retailer $\rightarrow$ Consumer

3: Farm Owner $\rightarrow$ Arathder $\rightarrow$ wholesaler $\rightarrow$ Wholesaler Cum Retailer $\rightarrow$ Retailer $\rightarrow$ Consumer

4: Farm Owner $\rightarrow$ Arathder $\rightarrow$ wholesaler $\rightarrow$ Hottle\& Restaurant

5: Farm Owner $\rightarrow$ Arathder $\rightarrow$ wholesaler $\rightarrow$ Faria $\rightarrow$ Consume

\section{Marketing cost and margin \\ Marketing cost of layer farm owner}

Layer farm owners performed the function of selling egg to arathder at farm. Total marketing cost incurred by the farm owners for 100 eggs was calculated at Tk. 3.23 (Table 1). Wastage accounted for about two-third of total cost $(64 \%)$, followed by personal expenses, cage and telephone bill.

Table 1. Marketing cost of layer farm owners

\begin{tabular}{lcc}
\hline Cost item & Cost (Tk./100 Eggs) & Percentage \\
\hline Wastage & 2.05 & 63.47 \\
Telephone bill & 0.35 & 10.83 \\
Personal expense & 0.45 & 13.93 \\
Cage & 0.38 & 11.75 \\
Total & 3.23 & 100.00 \\
\hline
\end{tabular}

\section{Total marketing cost of egg intermediaries}

Nature and extent of marketing cost varied from trader to trader. The total cost of marketing of egg included all costs incurred by different types of intermediaries operated between the producers and consumers. Arathder incurred the highest cost of Tk 20.60 per 100 eggs, followed by wholesaler (Tk 16.34), wholesaler cum retailer (Tk 13.09), and retailer (12.51) (Table 2). The total marketing costs incurred by all intermediaries were calculated at Tk. 62.54 per hundred eggs. Transportation cost was the highest cost comprising 37.26 percent of the total marketing cost. The second largest cost item was the rent of shop (14.13\%), followed by salary $(12.60 \%)$ and wastage $(12.34 \%)$.

Table 2. Marketing cost of intermediaries (Tk. per 100 eggs)

\begin{tabular}{|c|c|c|c|c|c|c|}
\hline Cost item & Arathdar & Wholesaler & $\begin{array}{l}\text { Wholesaler } \\
\text { cum retailer }\end{array}$ & Retailer & Total & percentage \\
\hline Transport & $8(38.83)$ & $6(36.71)$ & $4.8(36.50)$ & $4.5(35.98)$ & 23.3 & 37.26 \\
\hline Rent of the shop & $2.89(14.05)$ & $2.4(14.68)$ & $1.98(15.12)$ & $1.56(12.47)$ & 8.83 & 14.13 \\
\hline Salary & $2.93(14.24)$ & $2.16(13.22)$ & $1.43(10.89)$ & $1.36(10.87)$ & 7.88 & 12.60 \\
\hline Electricity & $1.86(9.01)$ & $1.53(9.35)$ & $0.95(7.22)$ & $0.69(5.48)$ & 5.02 & 8.02 \\
\hline Market tool & $0.53(2.57)$ & $0.43(2.63)$ & $0.42(3.22)$ & $0.32(2.56)$ & 1.7 & 2.72 \\
\hline Wastage & $1.96(9.50)$ & $1.9(11.63)$ & $1.96(14.97)$ & $1.9(15.22)$ & 7.72 & 12.34 \\
\hline Market security & $0.53(2.55)$ & $0.42(1.59)$ & $0.25(1.93)$ & $0.15(1.22)$ & 1.35 & 2.16 \\
\hline Telephone & $0.57(2.76)$ & $0.53(3.22)$ & $0.25(1.87)$ & $0.16(1.25)$ & 1.5 & 2.39 \\
\hline Personal & $0.76(3.67)$ & $0.66(4.01)$ & $0.46(3.49)$ & $0.2(1.60)$ & 2.07 & 3.31 \\
\hline Cage & $0.5(2.43)$ & $0.3(1.84)$ & $0.24(1.85)$ & $1.52(12.15)$ & 2.56 & 4.10 \\
\hline $\begin{array}{l}\text { Loading and } \\
\text { unloading }\end{array}$ & $0.03(0.12)$ & $0.02(0.12)$ & - & - & 0.05 & 0.07 \\
\hline Miscellaneous & $0.06(0.24)$ & - & $0.36(2.77)$ & $0.15(1.20)$ & 0.57 & 0.91 \\
\hline Total & 20.6 & 16.34 & 13.09 & 12.51 & 62.54 & 100 \\
\hline
\end{tabular}

*Figures in the parentheses indicate percent of total within each intermediary.

\section{Marketing Margin}

The portion of consumer's price that goes to marketing intermediaries is referred to as the marketing margin. In this section both gross and net marketing margin of eggs were calculated separately for different intermediaries. Gross margin was calculated by subtracting the value of purchase of eggs from their value of sales proceeds and net margin (profit) was calculated by subtracting the total marketing cost of eggs from the gross margin. Marketing margins of different intermediaries of eggs are shown in the Table 3. 
Table 3. Marketing margin of intermediaries (Tk. / 100 eggs)

\begin{tabular}{cccccc}
\hline Intermediaries & Purchase Price & Sale price & $\begin{array}{c}\text { Gross marketing } \\
\text { margin }\end{array}$ & Marketing cost & $\begin{array}{c}\text { Net marketing } \\
\text { margin }\end{array}$ \\
\hline Arathdar & 570 & 600 & 30 & 20.60 & 9.40 \\
Wholesaler & 600 & 630 & 30 & 16.34 & 13.60 \\
Wholesaler cum retailer & 630 & 665 & 35 & 13.09 & 21.91 \\
Retailer & 635 & 680 & 45 & 12.50 & 32.50 \\
\hline
\end{tabular}

Retailers enjoyed the largest gross as well as net margins. This is reasonable in the sense that as a perishable commodity they assume more risk because of keeping longer time for sale. The second highest net margin was for wholesaler cum retailer. By contrast, arathders received the lowest net margin because of the fact that they incurred the highest marketing cost compared with other traders.

\section{Price Spread}

The price spread refers to the difference between the price paid by the consumer and price received by the producer for an equivalent quantity of farm produce (Acharya and Agarwal 1999). The concept of price spread is of great significance in the study of marketing of egg. 'Knowledge of price spreads gives an insight into how income is distributed among producers and middlemen. If the layer farmers do not get adequate prices for their egg, they will be discouraged to expand or even continue production Incentive prices for farmer's can be ensured through an efficient system of marketing. In the present study, the channels selected for calculating price spreads are:

Channel 1: Farm owner $\rightarrow$ Arathder $\rightarrow$ Wholesaler $\rightarrow$ Retailer $\rightarrow$ consumer

Channel 2: Farm owner $\rightarrow$ Arathder $\rightarrow$ Wholesaler $\rightarrow$ Wholesaler cum retailer $\rightarrow$ consumer

The price spreads for different marketing channels of egg were worked and are shown in Table 4. The producer's net share of consumer's taka stood at 83.34 percent for channel 1 and 84.59 per cent for channel 2. It was higher for channel 2 against channel 1. So, Channel 2 seems to be more efficient than channel 1 . This very unusual in the sense that earlier studies for different crops showed that farmers' share decreased with increased of number of intermediaries in the marketing chain.

Table 4.Price spreads in different marketing channels of egg (Tk/100 Egg)

\begin{tabular}{lcccccc}
\hline Channel & Retail price & Farmer's price & $\begin{array}{c}\text { Farmer's net } \\
\text { price }\end{array}$ & Price spread & $\begin{array}{c}\text { Farmer's gross share(\% of Farer's net shared (\%of } \\
\text { retail price) }\end{array}$ & retail price) \\
\hline Channel 1 & 680 & 570 & 566.77 & 110 & 83.82 & 83.34 \\
Channel 2 & 670 & 570 & 566.77 & 100 & 85.07 & 84.59 \\
\hline
\end{tabular}

\section{MarketingEfficiency}

Marketing efficiency is essential for measuring the degree of marketing performance. On the basis of three methods for measuring marketing efficiency, channel 2 is more efficient (Table 5). In channel 2 the consumer paid lower price per 100 eggs compared to channel 1.though in practice channel 1 is mainly used for selling eggs in the study area.

Table 5.Marketing efficiency of egg in Gazipur market

\begin{tabular}{|c|c|c|c|}
\hline Particulars & Unit & \multicolumn{2}{|c|}{ Amount } \\
\hline 1. Price paid by consumers & $\mathrm{Tk} / 100$ eggs & 680 & 670 \\
\hline 3. Total net margins & $\mathrm{Tk} / 100$ eggs & 55.50 & 44.91 \\
\hline 4. Net price received by farmers & Tk/100 eggs & 566.77 & 566.77 \\
\hline
\end{tabular}

\section{Market Integration}

The degree of interrelationships between price movements in two markets iscalled market integration. In other words, in an integrated market, price of a homogeneous commodity at different spatially separated locations should tend to move together indicating efficient spread of price information and inter-linkages of markets. In interlinked commodity market price movement in one location should be highly correlated with price movement in other locations. 


\section{Integration by Co-integration Method}

To avoid the problem of spurious correlation between time series variables especially price variable, co-integration method was used which was developed by Engle and Granger (1987) for making firm decisions on market integration. The valuable contribution of the concepts of unit root, co-integration, is to force to find out if the regression residual are stationary (Gujarati, 2004, p. 822). As Granger (1987), notes, "A test for cointegration can be thought of as a pre-test to avoid spurious regression situations."

An intuitive explanation of the main concepts of co-integration analysis is that prices move from time to time, and their margins are subject to various shocks that drive them apart or not. If in the long run they exhibit a linear constant relation, it can be said that they are co-integrated. Granger representation theorem (Engle and Granger, 1987) tests that if a set of variables are co-integrated or integrated of order 1, denoted by I (1), there exists a valid error correction representation of the data. Converse of this theorem also holds, i.e., if an error correction model (ECM) provides an adequate representation of the variables, they must be co-integrated. The rationale behind the error correction model is that economic variables often exhibit long run equilibrium while retaining disequilibrium in the short-run. However a proportion of disequilibrium in one period can be corrected in the next period. For instance, price changes in one period may depend upon surplus demand of the previous period. Hence it is possible to recognize the short-run and long-run behavior through an error correction mechanism. The detail method is as follows:

\section{Co-integration Test for Eggs}

To test the stationary of the prices of eggs, the DF and ADF tests for wholesale price of eggs were conducted. ADF test was applied in case where serial correlation exists and that could be found from the Durbin Watson statistic (d-value). The tau $(\tau)$ statistics compared with critical values indicate that the null hypothesis is accepted and concluded that the eggs prices of all markets contained unit root. That means the price series for all markets are non-stationary.

The next step is to examine whether bivariate co-integration exists among different districts eggs prices. The researcher's aim was to find that which market's price influences others. It is normally assume that Dhaka is the reference market and it influences other markets prices. As data on prices of eggs for Dhaka, Chittagong, Rajshahi, Khulna, Sylhet, Mymensingh and Gazipur was available from DAM's weekly price report from the year of 2000 to 2010 , so the available data were used for the analysis. In Table 6 . The results of estimated co-integration regression and the final result were presented. The Engle-Granger (EG) tests of residual or error term confirmed the stationary of the residual series for all groups of two markets. Thus the results indicated that the residual series (which are linear combination of egg price series) are stationary at level I (0). That means yet the original price series being non-stationary but their linear combination being I $(0)$, the series are co-integrated.

Table 6. Spatial Price Relationships between different Markets for Eggs from 2000 to December 2011

\begin{tabular}{|c|c|c|c|}
\hline Markets & Co-integrating Regression & $\begin{array}{c}\text { Co-integration Test } \\
\text { Engel-Granger }\end{array}$ & Decision \\
\hline Dhaka-Chittagong & $\begin{array}{l}\mathrm{P}_{\mathrm{D}}=17.316+0.869 \mathrm{P}_{\mathrm{C}} \\
\mathrm{R}^{2}=0.891\end{array}$ & $\begin{aligned} \Delta \mathrm{U}_{\mathrm{t}}= & -0.743 \mathrm{U}_{\mathrm{t}-1} * * * \\
& (-8.893)\end{aligned}$ & Co-integrated \\
\hline Dhaka-Rajshahi & $\begin{array}{c}\mathrm{P}_{\mathrm{D}}=3.53+0.985 \mathrm{P}_{\mathrm{R}} \\
\mathrm{R}^{2}=0.892 \quad(32.664)\end{array}$ & $\begin{aligned} \Delta \mathrm{U}_{\mathrm{t}}= & -0.628 \mathrm{U}_{\mathrm{t}-1} * * * \\
& (-7.632)\end{aligned}$ & Co-integrated \\
\hline Dhaka-Khulna & $\begin{array}{c}P_{D}=16.202+0.96 P_{K} \\
R^{2}=0.895\end{array}$ & $\begin{aligned} \Delta \mathrm{U}_{\mathrm{t}}= & -0.716 \mathrm{U}_{\mathrm{t}-1} * * * \\
& (-8.581)\end{aligned}$ & Co-integrated \\
\hline Dhaka- Sylhet & $\begin{array}{c}\mathrm{P}_{\mathrm{D}}=18.93+0.87 \mathrm{P}_{\mathrm{S}} \\
\mathrm{R}^{2}=0.886 \quad(21.75)\end{array}$ & $\begin{array}{c}\Delta \mathrm{U}_{\mathrm{t}}=- \\
(-7.30)\end{array}$ & Co-integrated \\
\hline $\begin{array}{l}\text { Dhaka- } \\
\text { Mymensingh }\end{array}$ & $\begin{array}{c}\mathrm{P}_{\mathrm{D}}=2.234+0.979 \mathrm{P}_{\mathrm{M}} \\
\mathrm{R}^{2}=0.884 \quad(31.413)\end{array}$ & $\begin{aligned} \Delta \mathrm{U}_{\mathrm{t}}= & -0.832 \mathrm{U}_{\mathrm{t}-1} * * * \\
& (-9.701)\end{aligned}$ & Co-integrated \\
\hline Dhaka-Gazipur & $\begin{array}{l}\mathrm{P}_{\mathrm{D}}=12.702+0.978 \mathrm{P}_{\mathrm{G}} \\
\mathrm{R}^{2}=0.801 \quad(22.90)\end{array}$ & $\begin{aligned} \Delta \mathrm{U}_{\mathrm{t}}= & -0.582 \mathrm{U}_{\mathrm{t}-1} * * * \\
& (-7.27)\end{aligned}$ & Co-integrated \\
\hline
\end{tabular}

Note: Figure within ( ) shows t-values of the regression coefficient.

Tau $(\tau)$ values (without constant) at $1 \%$ and $5 \%$ level of significance are -2.55 and -1.95 respectively in the equation.

$* * *$ indicates $1 \%$ level of significance.

** indicates $5 \%$ level of significance.

Source: Department of Agricultural Marketing (DAM 2000-2011)

As mentioned earlier, Gazipur is surplus area in eggs production and the rest districts considered in the study are deficit area, so when price changes in this surplus area then automatically prices will changes for the other districts.

Finally, the result implies that if any divergence from long-run equilibrium occurs in period t-1, it will be adjusted towards equilibrium level in period t. Thus, the selected egg markets in Bangladesh are shown to be 
integrated. This is mainly attributed to close proxy, good communication facilities especially development of cell phone technology and good infrastructure availabilities among the market centers in Bangladesh.

\section{Problems identified}

The present study identified some problems and constraints associated with layer farming and egg marketing. The problems faced by the layer farm owners were categorized into economic, technical, marketing, social and natural problems. The economic and technical problems were: lack of capital, high feed price, nonavailability of day-old-chicks, lack of training facilities, inadequate knowledge of poultry diets, irregular supply of electricity, inadequate supply of vaccine and medicine. Marketing problems included fluctuation of demand, breakage of egg price fluctuation, and lack of transportation facilities. Outbreak of disease, natural calamities and environmental pollution were identified as the major social and natural problems. Problems faced by the intermediaries were: poor communication and transportation system, shortage of capital, lack of storage facilities, breakage of egg, price instability, unfavorable condition like hortal, strike, flood and natural calamities etc.

Some measures were suggested by the layer farm owners and traders for the solving the problems identified. Measures suggested by the farm owners included establishment of hatchery, adequate supply of feed at reasonable price, government intervention for capital, development of disease diagnostic facilities, provision of adequate supply of medicine and veterinary service, regularity in electricity supply, price stability, development of market information etc. Measures suggested by the traders were provision of institutional credit, development of storage facilities, adequate market space and facilities, improvement of market information and communication system etc.

\section{Conclusion}

On the basis of the findings of this study, some recommendations are put forward with a view to improving the production as well as marketing of egg in the study area.Financial institutions and NGOs should provide credit facility at easy terms and conditions to egg traders to meet cash need.Extension service needs to be strengthened for imparting training on improved feeding, housing, nutrition, management and disease control measures.For the great interest of layer farming, the government should provide incentive to the private pharmaceuticals industries to come forward to supply necessary medicines and vaccines for egg production at reasonable prices.Regular electricity supply should be ensured to operate the layer farming and egg trading.Communication and transportation system must be developed to increase the efficiency of egg marketing system. Adequate transportation facilities should be made available for carrying egg from farm yard to market for reducing wastage of egg.Strict policy needs to be formulated to protect the infant industry from the effect of price instability and demand fluctuation.The study also recommends that the expansion of layer farming and egg marketing is necessary for the creation of employment both in rural and urban areas. Government, private entrepreneurs and different NGOs can play an important role for development of egg production and marketing in the country.

\section{References}

[1]. Acharya, S.S. and N.L. Agarwal (1999): Agricultural Marketing in India. 4th Edition, Oxford and IBH Publishers, Calcutta

[2]. BBS(2000). Bangladesh Bureau of Statistics: Statistical Year Book of Bangladesh. Ministry of Planning, Government of the Peoples Republic of Bangladesh.

[3]. Engle, R. F. and Granger, C. W. J. (1987), "Co-integration and Error Correction: Representation, Estimation and Testing". Econometrica, Vol. 55 (2): 251-276.

[4]. GOB. Government of Bangladesh (2010): Report on the Economic Survey of Bangladesh. Ministry of Finance, Ministry of Planning, Government of the Peoples Republic of Bangladesh, Dhaka.

[5]. MoF. Ministry of Finance (2011). Bangladesh Economic Review. Finance Division Government of the People's Republic of Bangladesh, Dhaka, Bangladesh.

[6]. Panday, R.K; S.P. Bhardwaj; K.P.S. Nirman; V.K. Mahajan. (1996): Economic Analysis of Price Behaviour and Marketig of Eggs. Indian Journal of Agricultural Marketing, Vol. 10(2), pp.66-69.

[7]. Patniak, K.U.S. (1989): Efficiency of Groundnut Marketing in India. 1st Edition.Discovey Publishing House, Delhi, India.

[8]. Sharman, V.K. and A.J. Singh. (1995): "Marketable Surplus of Eggs in Punjab", Bihar Journal ofAgricultural Marketing vol. 3; No. 1.

[9]. Tomek, W.G. and L.K. Robinson (1990): Agricultural Product Prices, London, Cornell University Press.

[10]. Yeasmin, M. (2005): Marketing System and Price Behavior of Eggs in Selected Area of Mymensingh district. Unpublished M.S. Thesis, Department of Co-operation and Marketing, Bangladesh Agricultural University, Mymensingh. 